\title{
Pohjoismaiden itsehallintoalueet rauhantyön näkökulmasta
}

Ahvenanmaa, Färsaaret ja Grönlanti

/Policy brief 
Pohjoismaiden itsehallintoalueet

rauhantyön näkökulmasta - Ahvenanmaa, Färsaaret ja Grönlanti

ISBN 978-92-893-4507-1 (PRINT)

ISBN 978-92-893-4508-8 (PDF)

http://dx.doi.org/10.6027/ANP2016:715

ANP 2016:715

(C) Pohjoismaiden ministerineuvosto 2016

Ulkoasu: Pernille Sys Hansen, Damp Design

Kannen valokuva: imagesubscription.com ja norden.org

Valokuva: norden.org \& imagesubscription.com

www.norden.org/nordpub

\section{Pohjoismainen yhteistyö}

Pohjoismainen yhteistyö on yksi maailman laajimpia alueellisia yhteistyömuotoja. Yhteistyön piiriin kuuluvat Islanti, Norja, Ruotsi, Suomi ja Tanska sekä Ahvenanmaa, Färsaaret ja Grönlanti.

Pohjoismaista yhteistyötä tehdään politiikan, talouden ja kulttuurin aloilla tärkeänä osana eurooppalaista ja kansainvälistä yhteistyötä. Pohjoismaisen yhteisön tavoitteena on vahva Pohjola vahvassa Euroopassa.

Pohjoismainen yhteistyö pyrkii vahvistamaan pohjoismaisia ja alueellisia etuja ja arvoja globaalissa maailmassa. Maiden yhteiset arvot lujittavat osaltaan Pohjolan asemaa yhtenä maailman innovatiivisimmista ja kilpailukykyisimmistä alueista.

\section{Pohjoismaiden ministerineuvosto}

Ved Stranden 18

DK-1061 København K

Puhelin (+45) 33960200

www.norden.org 


\section{Johdanto}

Pohjoismaiden itsehallintoalueet ovat saaneet paljon huomiota viime aikoina. Entistä levottomammassa maailmassa Ahvenanmaan, Färsaarten ja Grönlannin itsehallintoratkaisuja pidetään tarkastelemisen arvoisena konfliktinratkaisun näkökulmasta. Ei vain Pohjoismaissa, vaan myös laajemmin kansainvälisesti on syytä ottaa oppia näiden itsehallintoalueiden huimasta kehityksestä sekä rauhan- omaisten ratkaisujen löytymisestä konflikteihin.

Pohjoismaiden neuvosto antoi tämän pohjalta Ahvenanmaan rauhaninstituutille tehtäväksi toteuttaa tutkimushankkeen, jossa tarkastellaan, mitä itsehallintoalueiden oikeudellista, taloudellista ja turvallisuuspoliittista kehitystä vertailemalla voidaan oppia. Osana hanketta Maarianhaminassa järjestettiin 26. tammikuuta 2015 myös konferenssi. Huhtikuussa 2015 valmistunut analyysi, jonka Sia Spiliopoulou Åkermark ja Gunilla Herolf ovat toimittaneet, on nimeltään Pohjoismaiden itsehallintoalueet rauhantyön näkökulmasta - Ahvenanmaa, Färsaaret ja Grönlanti (Självstyrelser i Norden i ett fredsperspektiv - Färöarna, Grönland och Åland).

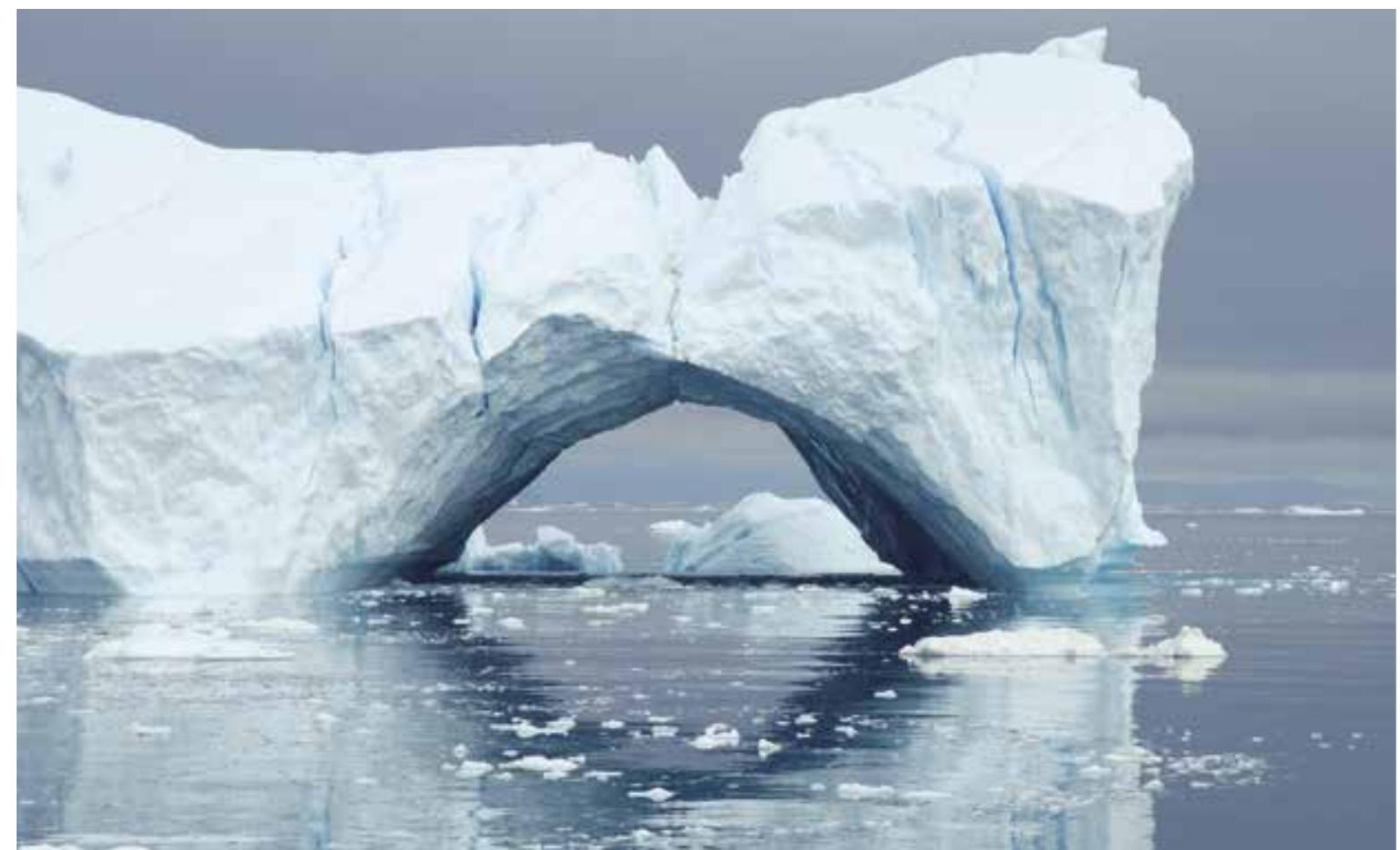




\section{Mitä olemme oppineet ja mitä voimme opettaa muille?}

Konflikteja voidaan ehkäistä ja ratkaista eri menetelmin. Tapoja on monia, kuten alla olevasta tiivistelmästä käy ilmi, ja vaikka aktiivisesti on haettava uusia ratkaisuja, on kuitenkin jo olemassa hyviä tapoja ja menetelmiä konfliktien välttämiseksi.

\section{Juridiset keinot}

Juridisia keinoja voidaan käyttää estämään itsehallintojen kehitystä, ja tämänkaltaisia syytöksiä on myös esitetty. On kuitenkin paljon todisteita myös päinvastaisesta eli juridisia keinoja on pääosin käytetty konfliktinratkaisun menetelmänä. Kuten Markku Suksi osoittaa kolmen pohjoismaisen itsehallinnon perustuslakeja vertailevassa tekstissään, itsehallinnon käyttöönotto on kääntänyt akuutin konfliktin luonteen päälaelleen, eräänlaiseksi latentiksi kiistaksi. Näin ollen Pohjoismaiden itsehallintoratkaisut voidaan nähdä konfliktinhallinnan perustuslaillisena menetelmänä. Tanskan toimintatapa ongelmien ratkaisemiseksi osapuolten välillä on mahdollisten konfliktien muuttaminen hallinnolliseksi käytännöksi valtion ja valtioon kuuluvan yksikön välillä, jolloin nämä kaksi osapuolta mukautuvat toisiinsa pikkuhiljaa.

\section{Kansainväliset järjestöt}

Kansainväliset järjestöt voivat monella tapaa osaltaan auttaa ehkäisemään tai ratkaisemaan konflikteja. Ne voivat toimia esimerkiksi tuomioistuimena. Ne soveltuvat hyvin tähän tehtävään, koska ne nähdään usein puolueettomampina kuin muut päätöksentekoelimet tai yksittäiset maat. Selkein pohjoismainen esimerkki tästä on Ahvenanmaan kysymyksen siirtäminen Kansainliiton ratkaistavaksi.

\section{Kansainväliset järjestöt voidaan} myös nähdä turvana. Esimerkkinä tästä voidaan mainita Ahvenanmaan kysymyksen kytkeminen Kansainliittoon tai Naton rooli kylmän sodan aikana Färsaarilla ja Grönlannissa, vaikkakin jälkimmäisen esimerkin voidaan myös tulkita lisäävän haavoittuvuutta Färsaarten ja
Grönlannin alueelle sijoitettujen tukikohtien takia. Toive turvallisuuden lisääntymisestä on ilmeisesti myös Grönlannin parlamentin ajatuksena sen toivoessa Thulen tukikohdan siirtämistä Yhdysvalloilta kansainväliseen omistukseen, jolloin toiminnasta tulisi läpinäkyvämpää.

Yksi tapa, jolla kansainväliset järjestöt voivat ehkäistä mahdollisen konfliktin syntymistä on se, että helpotetaan asteittaista integraatiota yhä itsenäisemmän aseman suuntaan tavalla, joka ei herätä vastustusta muissa. Sarah Stephanin tekstissä kuvaillaan itsehallintoalueiden integraatiota Pohjoismaiden neuvostoon esimerkkinä tällaisesta politiikasta. Se selittyy kekseliäisyydellä, jolla Pohjoismaiden neuvosto on onnistunut kiertämään kysymyksen itsehallintoalueiden täydestä jäsenyydestä, ja pyrkinyt sen sijaan integroimaan alueet muulla tapaa toimintaansa.

\section{Pakettiratkaisut}

Tärkeimpien tarpeiden ja mahdollisten ongelmien sisällyttäminen 

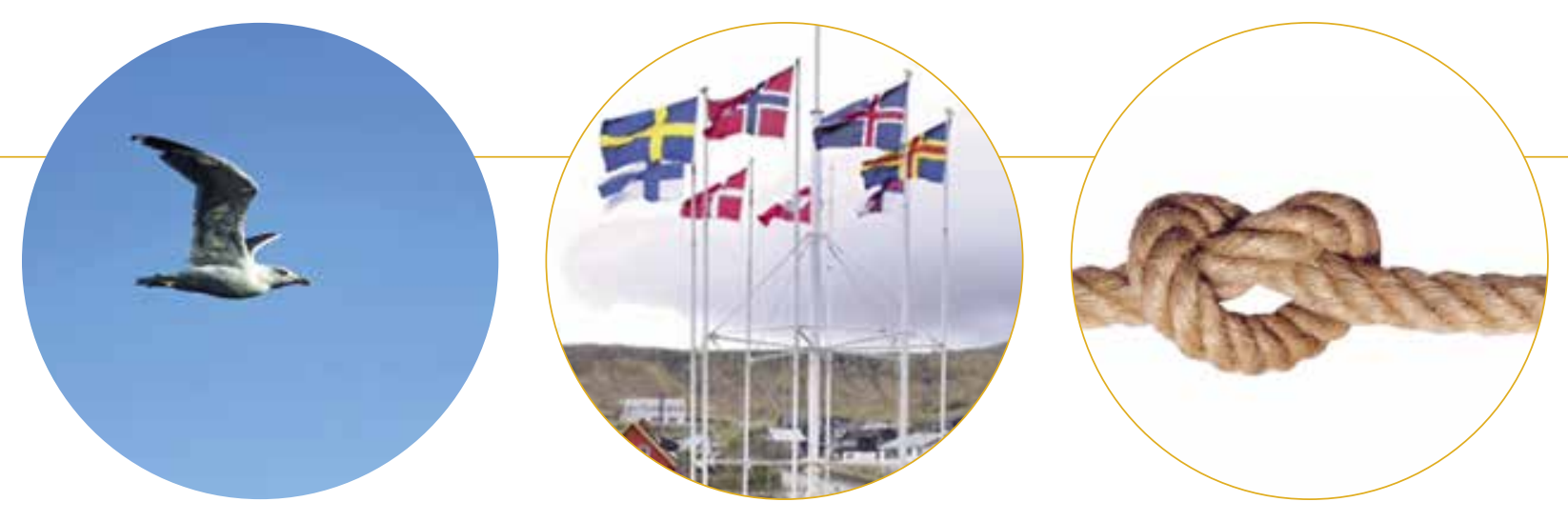

ehdotettuun ratkaisuun kokonaispakettina voi olla arvokasta sitä kautta, että kestävän sopimuksen todennäköisyys on suurempi. Ahvenanmaan osalta käytettiin niin kutsuttua pakettiratkaisua. Kuten Sia Spiliopoulou Åkermark kirjoittaa luvussa "Ahvenanmaa - jatkuvassa muutoksessa oleva ratkaisu ja rauhanesimerkki", ratkaisulla säädellään neljää tiettyä osa-aluetta: 1) poliittista vallanjakoa, 2) turvallisuuspoliittista tarvetta, 3) kulttuurista ja kielellistä tarvetta ja 4) taloudellista kestävyyttä.

\section{Joustavuus}

Sopimuksen on oltava jonkin verran joustava ollakseen kestävä. Pohjoismaiden itsehallintojen lainsäädäntöön tällainen joustavuus on sisällytetty eri tavoin. Näin eri toimivaltojen luetteleminen voidaan nähdä eräänlaisena joustavuutena; sen sijaan, että luodaan kovia rajoja, asioita voi- daan siirtää listalta toiselle ilman sen suurempaa dramatiikkaa. Kári á Rógvi pitää Färsaarten vuoden 1948 lakia nerokkaana ratkaisuna, joka osoittaa eräänlaista juridista mielikuvitusta, koska Färsaaret voi itse hallinnoimiensa osa-alueiden (erityisalueet) lisäksi valita osallistuvansa joihinkin kysymyksiin niin kutsuttujen yhteisten osa-alueiden puitteissa yhdessä Tanskan kanssa. Näin on luotu pohja myös muille joustavuuden muodoille. Joustavuus voi näkyä myös pragmaattisuutena. Sjúrdur Skaale kuvasi konferenssissa Tanskan nykypolitiikkaa esimerkkinä fiksusta joustavuudesta, sillä hallitus valitsee toimivia ratkaisuja, vaikka ne välillä ovatkin perustuslain vastaisia.

\section{Pohjoismainen identiteetti}

Yksi konflikteja ehkäisevä tekijä on yhteinen pohjoismainen identiteetti. Tähän kuuluu, että naapurit tunnetaan hyvin, jolloin konfliktien yhteydessä väistämättä syntyvät väärinymmärrykset ovat merkitykseltään vähäisempiä kuin muualla maailmassa.

Huomattava poikkeus tähän on Grönlannin inuiitit ja Tanskan entinen rooli siirtomaaherrana. Suurimmat konfliktit liittyvät juuri tähän kysymykseen. Grönlanti poikkeaa myös muista alueista taloudellisten ja sosiaalisten ongelmien osalta, mikä käy selväksi Richard Palmerin taloudellista ja sosiaalista hyvinvointikehitystä kuvaavassa luvussa. Konflikteja on ollut etenkin sillä ajanjaksolla, kun Grönlannin väestö ei vielä ollut järjestäytynyt poliittisiin puolueisiin näkemystensä edistämiseksi. Tanskassa on myös noussut toistuvasti esiin kanta Grönlannin väestön kohtelusta. Se on synnyttänyt keskustelua, joka on vaikuttanut hallitukseen.

Itsehallintoalueiden asukkaat kuuluvat vähemmistöön Tanskassa ja Suomessa, vaikka he - inuiitte- 
ja lukuun ottamatta - poikkeavat valtaväestöstä vain marginaalisesti tyypillisten vähemmistökriteerien, kuten kielen ja kulttuurin, osalta. Saamelaisista poiketen heillä on kaikilla oma erillinen alueensa, ja he kokevat olevansa oma yksikkönsä. Heidän toiveensa omasta hallinnosta ei juonnu sorrosta ja väkivallista, mikä on tyypillistä muualla maailmassa ja mikä vaatii kattavaa sovittelua. Sen sijaan se pohjautuu toiveeseen saada päättää itse omista asioista kokonaan tai osittain, säilyttää oma erityisluonne ja hallita itse alueen resursseja ja taloutta.

Identiteetti on siis ollut vahva tekijä ja kytkeytynyt etenkin kulttuuriin. Tämä käy ilmi myös Maria Ackrénsin luvusta, jossa hän analysoi Grönlannin parlamentaarista kehitystä. Tove H. Malloy osoittaa, että suhde Grönlannin väestöön on muuttunut dramaattisesti, ja on selvää, että oppimiskokemukset ovat tulleet asteittain, eivät ilman konflikteja.

Rauhanomainen prosessi ei suinkaan tarkoita, etteikö suhteissa olisi kahnausta, ja Lise Lyckin esimerkit Färsaarten perustuslaillista asemaa käsittelevässä tekstissä osoittavat, miten taloudelliset tekijät ovat muuttuneet entistä tärkeämmiksi rauhanomainen prosessi tarkoittaa, että konflikteja voidaan hallita rauhanomaisella tavalla myös tämän päivän monissa kiistoissa. Ajatus siitä, että nämä kiistat johtaisivat kriittiseen tilanteeseen, on kuitenkin erittäin epätodennäköinen.

Pohjoismaiden menestys rauhanomaisessa konfliktinratkaisussa ei saa kuitenkaan johtaa ylimielisyyteen. Pohjola on päässyt pitkälle tässä asiassa, mutta opetukset ja tietämys ovat kertyneet vähitellen ja uudet haasteet voivat laittaa ratkaisut koetukselle. Elämme aikana, jolloin Euroopassa on taas alettu käyttää aseita, emmekä voi olla varmoja siitä, mitkä ulkoapäin tulevat uhat voivat kohdistua yksittäisiin maihin ja alueisiin Pohjoismaissa.

\section{Mitä kokemuksia voidaan siirtää kansainväliselle tasolle?}

Pohjoismaiden ja muun maailman edellytysten vertailu itsehallintoalueisiin liittyvien konfliktien ehkäisemissä ja ratkaisemissa osoittaa, että Pohjolassa on tiettyjä suotuisia olosuhteita, joita ei juurikaan esiinny muilla alueilla. Yksi näistä on yhteispohjoismainen identiteetti, joka on jokseenkin ainutlaatuinen Pohjoismaille. Toinen etu kriisienhallinnalle Pohjoismaissa on se, että asianomaisten lisäksi mikään ulkopuolinen taho ei ole yrittänyt ohjailla kriisejä ulkoapäin omiin tarkoituksiinsa suotuisalla tavalla. Kolmas tekijä on pohjoismainen luottamuksen perinne. Luottamuksesta yhteiskuntaan kertoo vahvasti
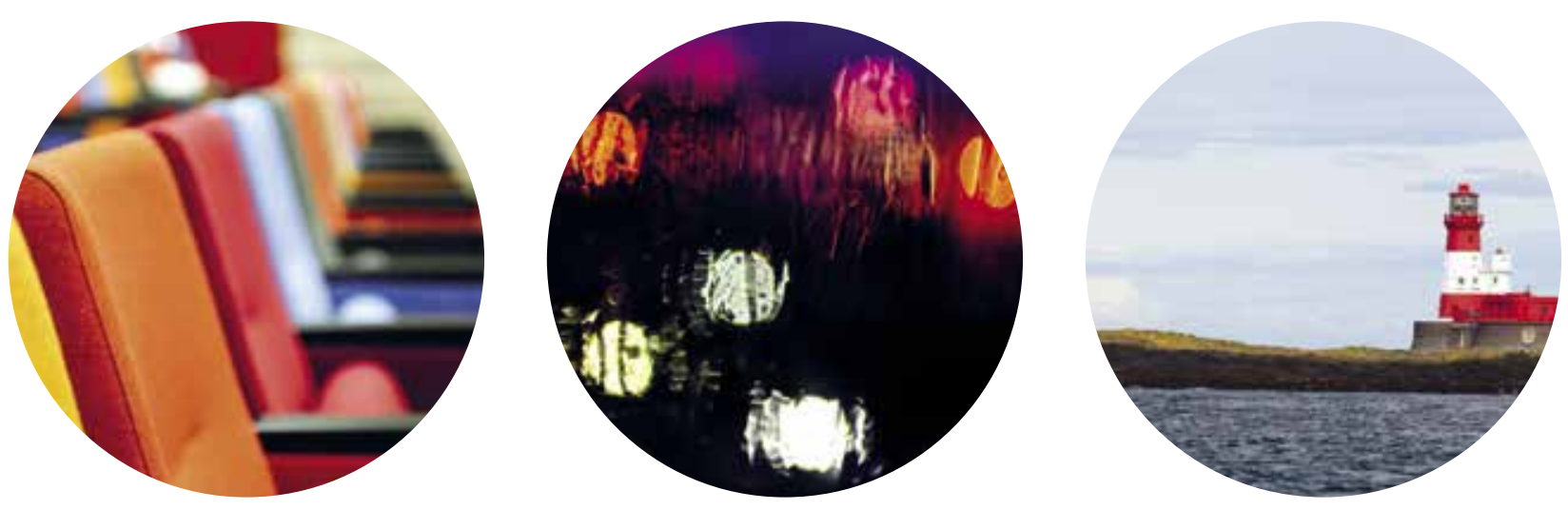

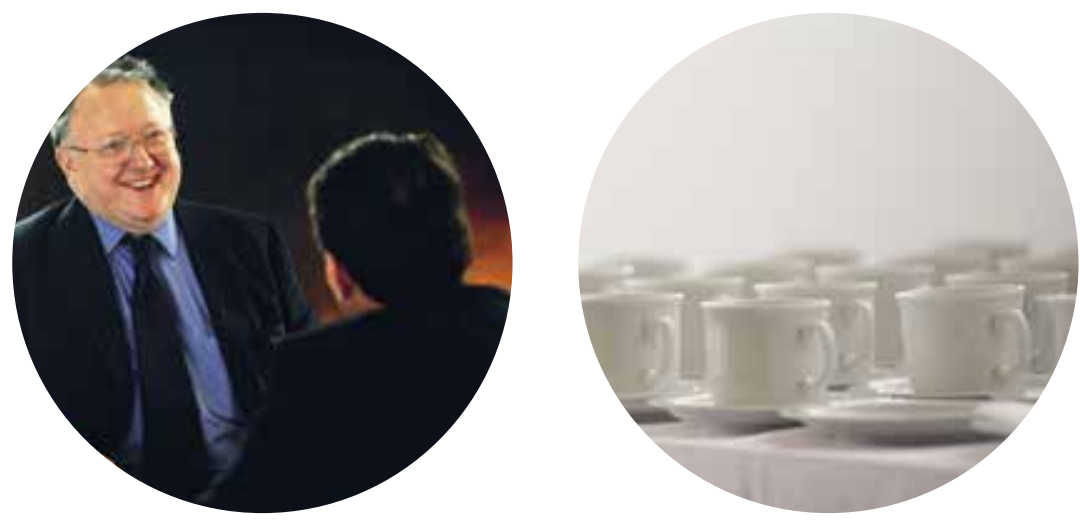

myös se, että vaikka Ruotsissa ja Ahvenanmaalla oltiin hyvin pettyneitä päätökseen, se kuitenkin hyväksyttiin. Tavallisesti pohjoismaalaiset luottavat myös vastapuoleen, mikä varmasti johtuu siitä, että Pohjoismaiden yhteiskuntarakenne on vakaa ja sopimusrikkomuksista koituu seurauksia.

Alueilla, joilla ei ole näitä samoja edellytyksiä, ongelmat ovat moninkertaisesti suurempia. Kysymys kuuluukin, voivatko pohjoismaiset konfliktinratkaisumekanismit toimia myös huomattavasti heikommissa olosuhteissa.

Väitetään, että voivat, tietyssä määrin ja samoja menetelmiä käyttämällä, jos odotukset ovat kohtuulliset. Kansainvälisiä järjestöjä voidaan käyttää eri tehtävissä samaan tapaan kuin Pohjoismaiden olosuhteissa. Tuomioistuimen rooli sekä rauhansopimuksen takuu ovat entistä tärkeämpiä ympäristössä, jossa ei ole valtiota, joihin voi luottaa. Kansainvälinen järjestö soveltuu hyvin valvomaan toimintaa, jos ilmassa on epäluottamusta ja tarvitaan läpinäkyvyyttä. Kansainvälinen järjestö voi myös rutiinien ja tarkastusten kautta tietyssä määrin kompensoida alueen luottamuspulaa.

Asteittainen menettelytapa, jossa itsehallintoja osallistetaan integraatioprosessiin ja jolla voi olla konfliktia ehkäisevä vaikutus, voi soveltua hyvin myös muille kuin pohjoismaisille organisaatioille ja muille maantieteellisille alueille.

Ahvenanmaan konfliktin ratkaisun osalta hämmästystä herättää se, miten onnistunut ratkaisu on ja miten tyytyväisiä konfliktin ratkaisuun nykyään ollaan. Se, että Ahvenanmaan ratkaisusta on tullut niin vakiintunut, on vahva viesti muille siitä, että se oli viisas ratkaisu. Siihen sisältyy useita hyviä osatekijöitä, joista tunnetuin on konfliktin vieminen ratkaistavaksi kansainvälisesti. Toinen on yllä mainittu pakettiratkaisu, johon sisältyy neljä tärkeää osa-aluetta. Tällainen ratkaisu voi olla vaikeampi saavuttaa Pohjoismaiden ulkopuolella, mutta sitä voidaan pitää entistä arvokkaampana, jos poliittiset olot ovat Pohjoismaita epävakaampia.

Yleisesti ottaen ratkaisut tulee sopeuttaa olemassa oleviin edellytyksiin samalla, kun pohjoismaisten ratkaisujen menestystekijät otetaan huomioon. Joustavuus ja käytännöllisyys ovat osoittautuneet tekijöiksi, joiden ansiosta sopimukset ovat toimineet hyvin. Tähän on vaadittu niin hyvää tahtoa kuin juridista mielikuvitustakin. Tällä tavoin konfliktit eivät katoa, vaan niitä käsitellään tavalla, joka pikemminkin heikentää kuin lietsoo niitä. Prosessia käydään kynän ja paperin sekä keskustelun ja sopimusten kautta eikä asein. 


\section{Tieteellinen käsittely}

\author{
Perustuslailliset yhtäläisyydet ja \\ erot Pohjoismaiden itsehallinto- \\ alueiden välillä \\ Markku Suksi
}

Pohjoismaiden itsehallintoalueet Ahvenanmaa, Färsaaret ja Grönlanti ovat samankaltaisia siinä suhteessa, että niihin ei vaikuta federaatioissa ja muissa autonomioissa tavanomainen etuoikeuslauseke. Tämä seikka tekee Pohjoismaiden itsehallintoalueista vahvoja suhteessa kansalliseen lainsäädäntöön. Ne ovat kuitenkin keskenään melko erilaisia, ja jopa Tanskan kaksi itsehallintoaluetta poikkeavat toisistaan. Näille kahdelle yksikölle on kuitenkin annettu sellainen epätavallinen toimivalta, että lainsäädäntövalta on siirretty kansalliselta lainsäätäjältä itsehallintoalueen lainsäätäjälle päätöksillä, jotka itsehallintoalueen oma lainsäätäjä on tehnyt. Periaatteessa kaikilla kolmella itsehallintoalueella on kuitenkin tietyt lainsäädäntövaltuudet, joita vastaa joukko kansallisen lainsäätäjän lainsäädäntövaltuuksia. Grönlanti on itsehallintoalue, jolle on myönnetty itsemääräämisoikeus ja mahdollisuus itsenäisyyteen syistä, jotka liittyvät inuiittiväestön asemaan alkuperäiskansana. Näyttää siltä, että itsehallinto on otettu käyttöön näillä kolmella alueella lyhytaikaisen avoimen konfliktin jälkeen niin, että konflikti on itsehallinnon avulla tuotu perustuslain piiriin, tehty latentiksi ja helposti käsiteltäväksi oikeusvaltion puitteissa.

\section{Kannattaako itsehallinto? Pohjoismaiden autonomioiden sodan- \\ jälkeinen hyvinvointikehitys}

Richard Palmer

Missä määrin Pohjoismaiden kolme poliittis-alueellista autonomiaa Ahvenanmaa, Färsaaret ja Grönlanti ovat voineet hyötyä itsemääräämisoikeudestaan ja lisätä sen avulla väestönsä kasvua ja hyvinvointia?
Analyysi perustuu sekä itsehallintoalueiden välisiin että itsehallintoalueiden ja emämaiden välisiin vertailuihin, joita on laadittu muun muassa väestönkehityksen, talouskasvun ja odotetun eliniän osalta. Päätelmä on se, että ainakin kaksi kolmesta itsehallintoalueesta, Ahvenanmaa ja Färsaaret, ovat hyvinvoinnin suhteen lähentyneet emämaitaan viimeisen 15 vuoden aikana. Ahvenanmaa on ainoa itsehallintoalue, jolla on jatkuvasti korkeampi hyvinvoinnin aste kuin emämaalla. Paikallaan polkeva väestönkasvu, heikot työmarkkinat ja jatkuvat psykososiaaliset ongelmat erottavat 
Itsehallinto ja alueellinen integraatio - pohjoismaisia ratkaisuja

Sarah Stephan

Itsehallintojen asemaa pohjoismaisessa yhteistyössä on tutkittu useassa yhteydessä: 1960-luvun lopulla, 1980-luvun alussa ja 2000-luvun puolivälissä. Kysymys itsehallintojen integraatiosta koskee kolmea ulottuvuutta: 1) itsehallinnon luonnetta, 2) kansainvälisen oikeuden seurauksia ja 3) käytännön edellytyksiä itsehallintojen integraatioon pohjoismaisen yhteistyön puitteissa. Kansainvälisen oikeuden näkökohdat olivat ratkaisevia pohdittaessa itsehallintojen vaikutusmahdollisuuksia sekä institutionaalisia puitteita. Itse asiassa vastuulliset komiteat ovat kiertäneet kysymyksen täydestä jäsenyydestä ja mahdollistaneet itsehallintojen integraation myös ilman Helsingin sopimukseen liittymistä. On luotu kahden valtuuskunnan järjestelmä, jolla on mahdollistettu itsehallintoalueiden edustus Pohjoismaiden neuvostossa, ja niillä on niin kutsuttu informed opt-in -mahdollisuus eli tiedon ja harkinnan perusteella mahdollisuus valita osallistuvansa Pohjoismaiden ministerineuvoston päätöksiin. Pohjoismaat ja jäsenmaat ovat osoittaneet tahtoa ja kykyä käsitellä kysymystä itsehallintojen integraatiosta ja mikä tärkeintä, kykyä mukauttaa institutionaalisia rakenteitaan sallimaan edustuksen ja osallistumisen tavanomaiseen "sisällä tai ulkona"-ajatteluun katsomatta. Kansainvälisten järjestöjen, kuten Pohjoismaiden neuvoston, kyky osallistaa ja sisällyttää itsehallintojaan institutionaalisiin rakenteisiinsa voi vaikuttaa siihen, miten itsehallinnot nähdään
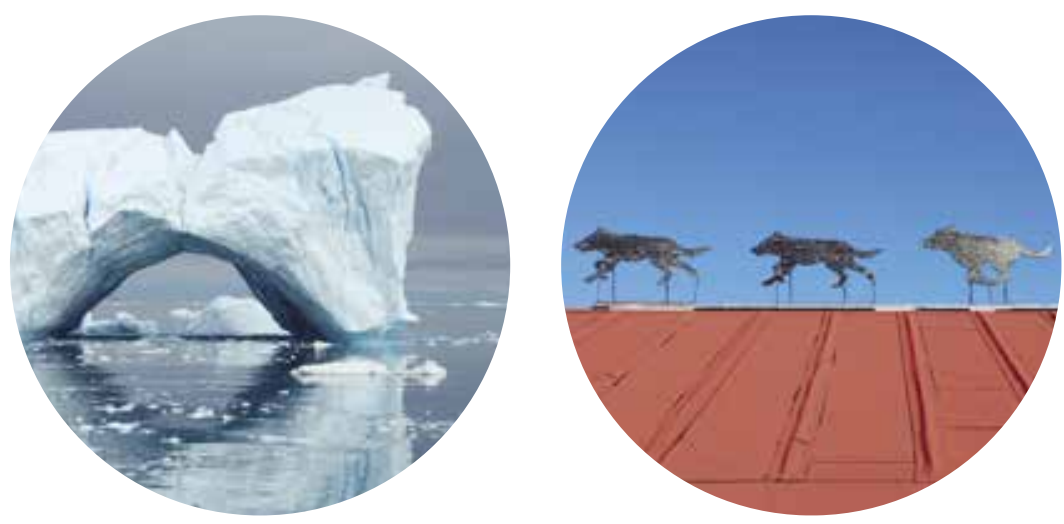

etenkin konfliktinratkaisussa, jossa integraatio voi olla ratkaiseva tekijä itsehallintoratkaisun tukemisen kannalta.

\section{Grönlannin poliittinen kehitys toisesta maailmansodasta nyky- aikaan}

Maria Ackrén

Grönlannin poliittista kehitystä toisesta maailmansodasta nykyaikaan voidaan tarkastella poliittisten puolueiden haluna itsehallintoon tai itsenäisyyteen. Kehitys on kulkenut Grönlannissa hurjaa vauhtia ja läheisessä yhteistyössä Tanskan kanssa. Komiteoihin ja neuvotteluihin on aina kuulunut yhtä monta tanskalaista ja grönlantilaista virkamiestä ja poliitikkoa. Monella perinteisellä grönlantilaisella poliittisella puolueella on myös tanskalainen sisarpuolue. Emämaan ja autonomian välillä on luonnollinen linkki. Lisäksi kehitystä on aina viety eteenpäin rauhanomaisella tavalla ilman suurempia konflikteja. Tanskan ja Grönlannin näkemykset eivät luonnollisesti aina ole kohdanneet täysin, mutta kiistat on ratkaistu hienostuneen diplomaattisesti. Kirjoitushetkellä parlamentin koalitio muodostuu kolmesta puolueesta: Siumut, Atassut ja Demokraatit. Hallituskoalition tavoitteena on tehdä 
työtä sen eteen, että Grönlannin kansainvälinen asema vahvistuisi ja että turvallisuutta ja luonnonvaroja koskevia kansainvälisiä sopimuksia noudatettaisiin.

\section{Tanskan rooli Grönlannin vapau- tuksessa - holhooja vai rauhan- rakentaja?}

Tove H. Malloy

Tanskan roolia Grönlannin kehityksessä ja vapauttamisessa toisen maailmansodan jälkeen voidaan parhaiten tarkastella kahdesta näkökulmasta: hyvän siirtomaaherran ja rauhanvälittäjän. Nämä roolit kietoutuneet erottamattomalla tavalla toisiinsa kolmen geopoliittisen syyn vuoksi. Grönlannin asemaan ja historialliseen perintöön ovat vaikuttaneet ulkoiset tekijät, kuten YK:n aikaisemmat päätöslauselmat, joiden tarkoituksena on ollut suojata itsehallintoalueita, Naton perustaminen ja Tanskan EU-jäsenyys, ja nämä ovat pyrkineet vaikuttamaan Tanskan poliittiseen kantaan.

Tämän vuoksi Tanskan hallitukset ovat joutuneet tasapainottelemaan kysymyksessä varovasti, mikä on tarkoittanut Grönlannin väestölle pitkää ja kivuliasta odotusta, mikä ei vieläkään ole ohi. Tässä luvussa käsitellään Tanskan hallitusten ja Grönlannin eliitin suhteita ensimmäisistä sodan jälkeisistä komissioista, joissa pohdittiin Grönlannin sisällyttämistä kuningaskuntaan 1953 aina itsehallinnollisen alkuperäiskansan tunnistamiseen vuonna 2009. Luvussa kuvaillaan aiempia institutionaalisia järjestelyjä ja pohditaan joitain sodan jälkeisen ajan herkimpiä kysymyksiä, kuten Grönlannin edustusta Tanskan parlamentissa, grönlantilaisten valtion virkamiesten avointa syrjintää ja oikeutta Grönlannin luonnonvaroihin. Käsitellään myös niitä näkökulmia, jotka liittyvät EU-suhteisiin sekä YK:n ja Yhdysvaltain rooliin. Postkolonialistisesta näkökulmasta ja kansainvälisten suhteiden normatiivisen tulkinnan lähtökohdista luvussa todetaan, että Tanska, jolla on ollut sekä hyvän siirtomaaherran että rauhanmeklarin roolit samanaikaisti, ei ole vain vienyt Grönlannin kansalta perusihmisoikeuksia, vaan myös harjoittanut arveluttavaa politiikkaa verhoutumalla rauhanvälittäjäksi.

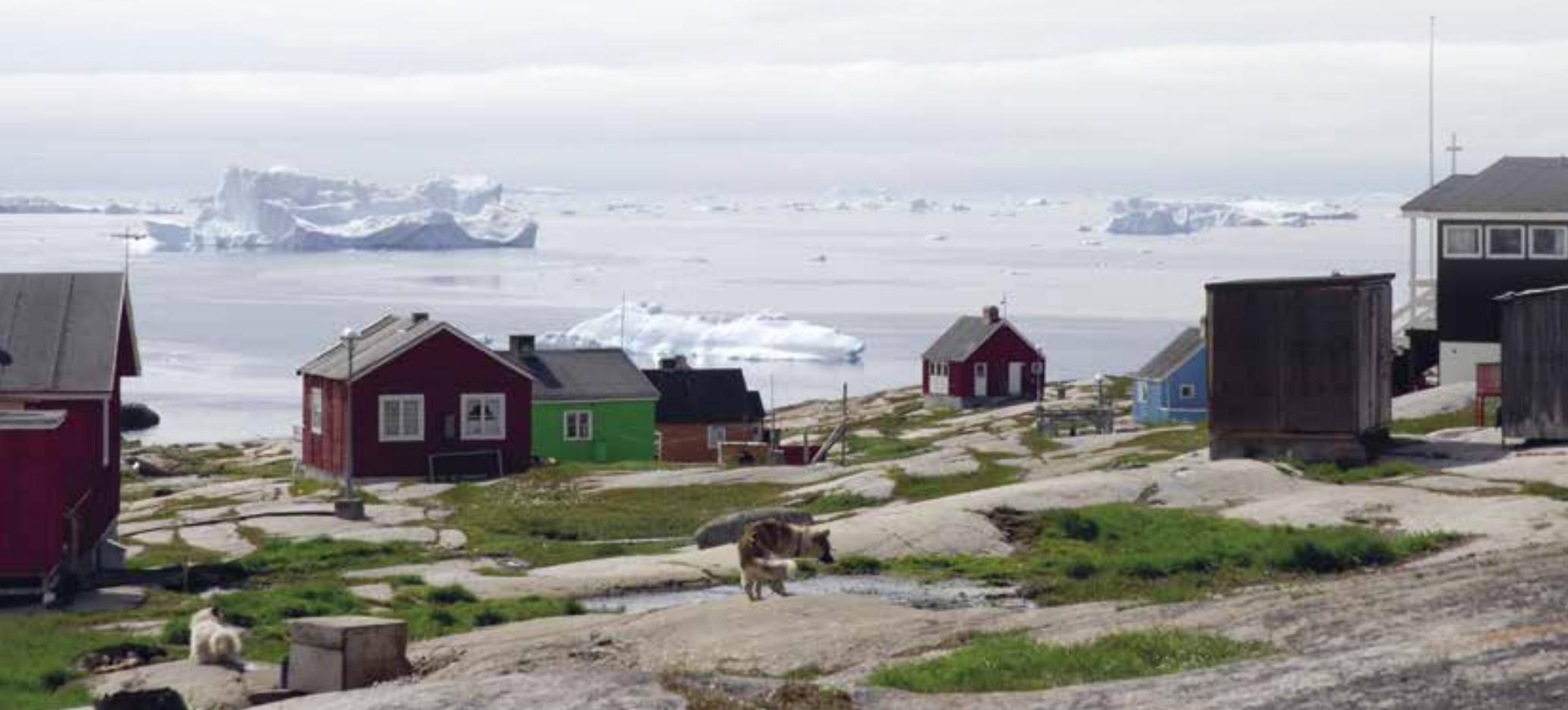




\section{Färsaarten perustuslaillinen asema toisen maailmansodan jälkeen nykyisiin taloushaastei- siin keskittyen \\ Lise Lyck}

Färsaaret on osa Tanskaa, ja sillä on perustuslaillinen järjestely, itsehallinto, mikä ei tarkoita täydellistä autonomiaa, vaan kattavia oikeuksia päättää maan omasta kehityksestä. Kun Tanska liittyi Euroopan talousyhteisöön (ETY) vuonna 1973,
Tanskan parlamentti antoi färsaarelaisille mahdollisuuden ottaa kantaa jäsenyyteen, ja Färsaaret päätti tuolloin, että se ei hae jäsenyyttä. Färsaaret sai tämän mahdollisuuden, koska ETYä (sittemmin Euroopan unioni) pidettiin tuolloin taloudellisena järjestelynä, ei instituutiona, joka oli kehittymässä poliittiseksi unioniksi. Taloudelle, joka Tanskasta poiketen perustuu yksinomaan kalastukseen, EU:n kehitys tekee erityisen hankalaksi käsitellä itsehallintoa tyydyttävällä tavalla. Luvussa esitellään ja analysoidaan kaksi vakavaa kriisiä: 1990-luvun pankkikriisiä, jolloin kaikki färsaarelaiset pankit menivät konkurssiin sekä myöhempää Atlantin makrillisotaa. Muualla maailmassa tällaiset kriisit olisivat johtaneet väkivaltaisiin konflikteihin, mutta näissä tapauksissa kriiseihin onnistuttiin - vaikkakin vaivalloisesti - saavuttamaan rauhanomainen ratkaisu.

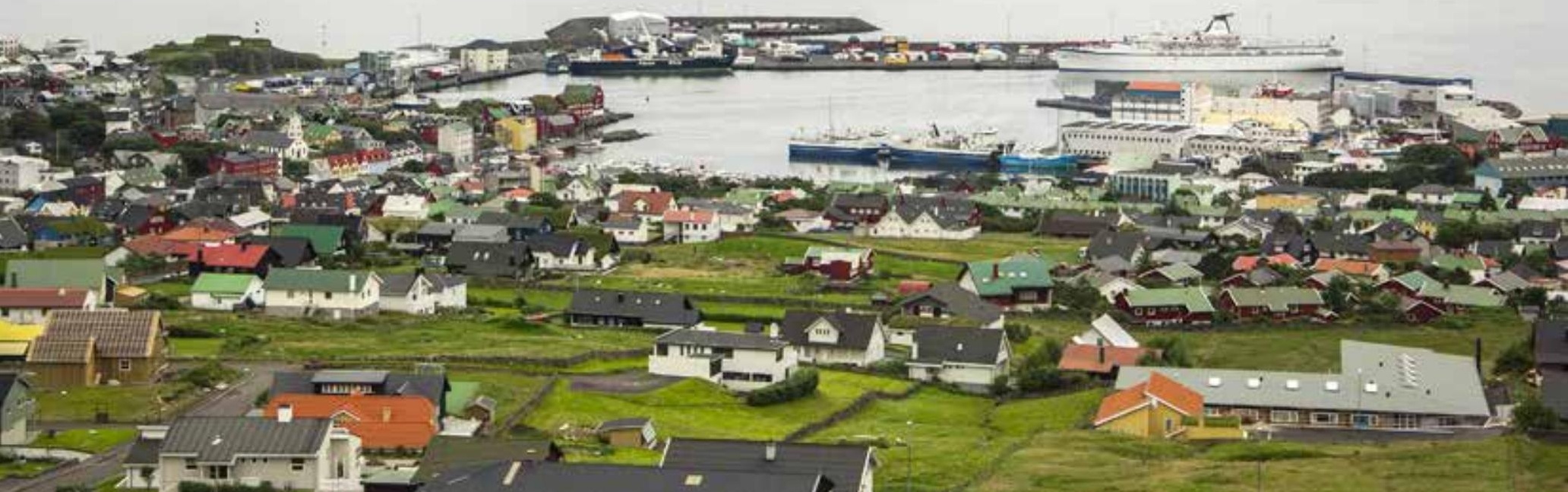


Färsaarten itsehallintolainsäädännön tarkistaminen Kári á Rógvi

Färsaaret ei ole välttynyt naapurisuhteissa ongelmilta. Myös nykyään on käynnissä kiistoja, jotka koskevat kalastuskiintiöitä, perustuslakia, kansainvälistä edustusta ja ennen kaikkea itsehallintoalueiden virallista jäsenyyttä Pohjoismaiden neuvostossa.

Färsaarten ja Tanskan välinen suhde on kehittynyt siten, että itsehallinto on vahvistunut. Färsaaret on asteittain saanut uusia lainsäädännöllisiä ja hallinnollisia valtuuksia, vaikkakin ulko- ja turvallisuuspolitiikan sekä valuutan osalta päätäntävalta on edelleen Tanskalla. Kehitys on johtanut yleisesti tyydyttävään tilanteeseen Färsaarilla, ja väestön mielipide on jakautunut itsenäisyyden kannatuksen osalta. Prosessi sinänsä ei kirjoittajan mukaan kuitenkaan ole ollut tyydyttävä. Suhteita on rasittanut juridisen mielikuvituksen puute ja Tanskan taipumus ratkaista konfliktit "accident and force" -menetelmää käyttäen pikemminkin kuin "reflection and choice" -ajattelun kautta. Färsaaret on tänä päivänä käytännönläheisen ja pohjoismaisen sivistyneen konfliktinratkaisun tulos, mutta haastetta lisää aiempi legalistinen konfliktihakuisuus.

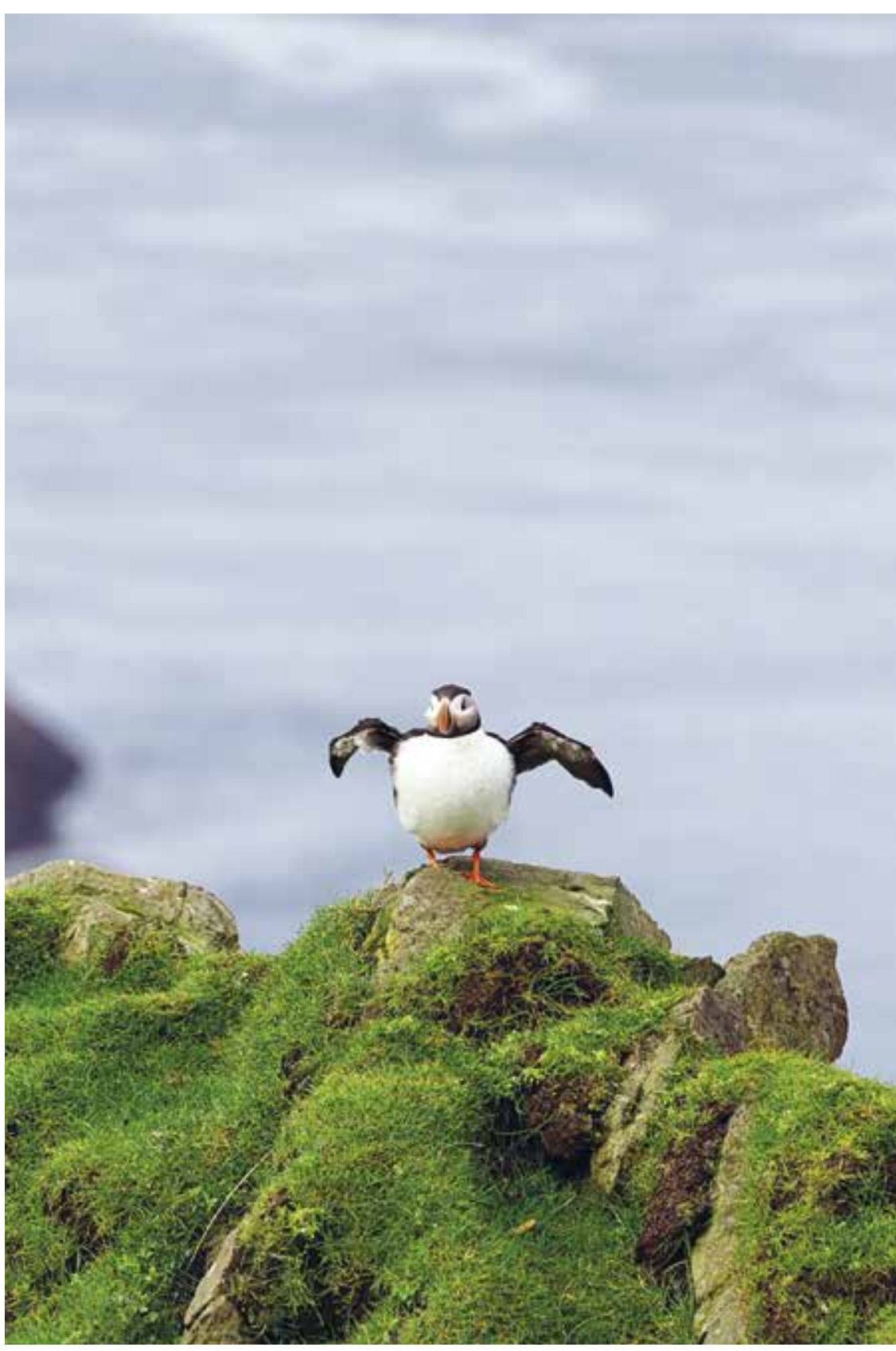




\section{Ahvenanmaa - jatkuvassa muu- toksessa oleva ratkaisu ja rauha- nesimerkki. Esimerkki mistä ja kenelle?}

Sia Spiliopoulou Åkermark

Juridiikka ja yhteiskuntatiede eivät voi ennustaa tai määrätä yhteiskunnalle tarkkoja menettelytapoja, mutta ne ovat arvokkaita yhteiskunnallisten ongelmien sekä niiden eri ratkaisujen hyvien ja huonojen puolten ymmärtämiseksi. On sanottu, että Ahvenanmaa on enemmän kuin malli - se on ajattelutapa. Miten sitten ajatellaan Ahvenanmaan mallin mukaisesti? Ahvenanmaan malli osoittaa konfliktiosapuolten tahtoa pitää kiinni kompromissista sekä kansallisella että kansainvälisellä tasolla. Mallia on kehitetty jo yli sadan vuoden ajan ja se käsittelee monitasoista tilannetta kokonaisvaltaisesti säätelemällä neljää keskeistä näkökulmaa: 1) poliittinen vallanjako ja päätöksenteko, 2) turvallisuusnäkökulmat Ahvenanmaan demilitarisoinnin ja neutralisoinnin kautta sekä Ahvenanmaan poliisia koskevat päätökset, 3) kulttuuriset ja kielelliset tarpeet, erityisesti koulutuksen osalta ja lopuksi 4) itsehallintoratkaisun taloudellinen kestokyky ja kestävyys. Ahvenanmaan malli on siten esimerkki kompromissista, joka on laillisesti, institutionaalisesti, perustuslaillisesti ja kansainvälisesti jalkautettu, mutta joka sisältää sääntöjä ja menettelyjä, jotka mahdollistavat tarkistuksen ja uudelleen neuvottelemisen, vaikka järjestelmän ydinosat säilytetään ja niitä kunnioitetaan. Ahvenanmaan kokemus pohjautuu olettamukseen, että yhteiskunta haluaa vahvistaa ja edistää vähemmistöjä ja että suvereniteetti ei ole nollapeli, vaan pikemminkin ominaisuus, jota voidaan jakaa. Se on samaan aikaan Suomen malli ja edellyttää suomalaista perustuslakiin perustuvaa yhteiskuntajärjestystä, joka kunnioittaa moninaisuutta ja oikeusvaltion periaatteita.

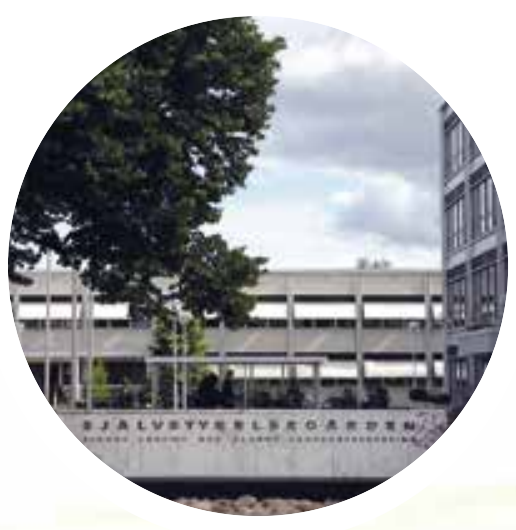




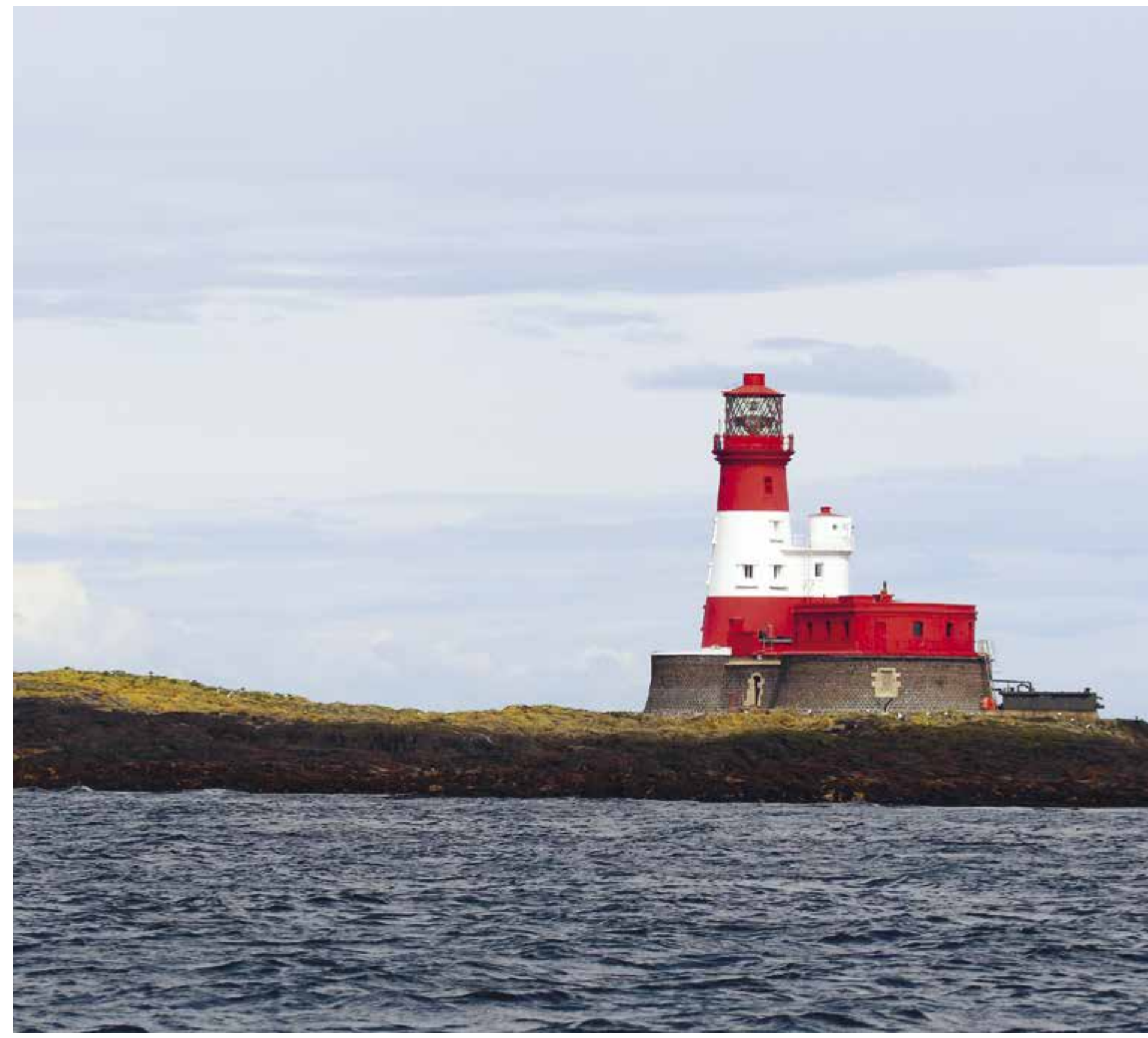




\title{
norden
}

\section{Pohjoismaiden neuvosto}

\author{
Ved Stranden 18 \\ DK-1061 København K \\ www.norden.org
}

\begin{abstract}
Pohjoismailla on kokemuksia rauhanomaisesta rinnakkaiselosta 200 vuoden ajalta. Näitä kokemuksia on hyvä tuoda esille ja ottaa niistä oppia. Alueellisen itsehallinnon kokemukset herättävät laajaa kansainvälistä kiinnostusta. Entistä levottomammassa maailmassa Ahvenanmaan, Färsaarten ja Grönlannin itsehallinnot nähdään arvokkaina esimerkkeinä konfliktinratkaisusta. Itsehallintoalueiden vahvaa kehitystä sekä rauhanomaisten ratkaisujen löytymistä konflikteihin on tärkeä tarkastella, ei vain pohjoismaisesta näkökulmasta, vaan myös laajemmin kansainvälisesti.
\end{abstract}

Tässä analyysissa esitellään Pohjoismaiden itsehallintojen oikeudellisen, taloudellisen ja turvallisuuspoliittisen kehityksen vertailevan tutkimuksen johtopäätelmät.

Julkaisun voi tilata kokonaisuudessaan Ahvenanmaan rauhaninstituutista - www.peace.ax

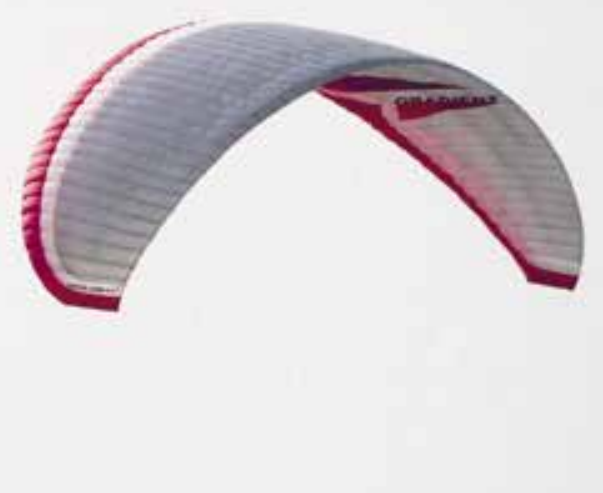

